\title{
CHARISMA AND SOCIAL MEDIA IN INDONESIAN POLITICS
}

\section{KARISMA DAN MEDIA SOSIAL DALAM POLITIK INDONESIA}

\author{
Ibnu Nadzir and Ranny Rastati ${ }^{1}$ \\ Research Center for Society and Culture - Indonesian Institute of Sciences (PMB LIPI) \\ Ibnu.nadzir@gmail.com, ranny.rastati@gmail.com
}

\begin{abstract}
The ability to exploit social media for political charisma is essential for aspiring Indonesian politicians. Social media is even more crucial for those who compete in urban areas, where its citizens have better access on digital technology. Nevertheless, study on the function of social media to develop political charisma is still relatively nascent. In this regards, the article explores the way politicians employ social media to get and maintain their power. How do social media affordances enable politicians to manufacture political charisma? To what extent, political charisma developed on social media enables politicians to influence their followers? To answer these problems, the article draws from the political trajectory of Ridwan Kamil, Governor of West Java, whose political persona relies heavily on his personal use of social media. Based on digital observation and several in-depth interviews, the article proposes three arguments. First, social media affordances enabled politician to construct political charisma based on multiple representations within a short period of time. Second, the infrastructure of social media has reinforced the blurry lines between personal and public matters in politics. Third, the influence of charisma developed through social media is constrained by social and political contexts.
\end{abstract}

Keywords: digital, social media, charisma, politicians, Indonesia

\section{ABSTRAK}

Kemampuan politisi menggunakan media sosial adalah keahlian yang amat penting bagi politisi-politisi generasi baru di Indonesia. Signifikansi teknnologi ini menjadi lebih krusial di wilayah perkotaan yang warganya memiliki akses lebih baik pada teknologi digital. Meskipun demikian, kajian yang mengangkat peranannya dalam pembentukan kharisma politik masih jarang. Dalam konteks tersebut, artikel ini mengeksplorasi penggunaan media sosial oleh politisi untuk memperoleh dan mempertahankan kekuasaannya. Bagaimana media sosial membantu politisi untuk membangun karisma politik? Sejauh apa karisma politik yang dibangun lewat media sosial berpengaruh pada para pengikutnya? Untuk menjawab pertanyaan tersebut, artikel ini mengangkat kasus perjalanan politik Ridwan Kamil, Gubernur Jawa Barat, yang amat mengandalkan media sosial dalam membangun karismanya. Berdasarkan pengamatan digital dan wawancara mendalam, artikel ini merumuskan tiga argumen utama. Pertama, karakteristik khusus media sosial membantu politisi membangun kharisma politik berdasarkan beberapa representasi publik yang ditampilkan. Kedua, infrastruktur media sosial semakin mengaburkan batasbatas isu personal dan publik dalam politik. Ketiga, pengaruh karisma yang dibangun melalui media sosial tetap dibatasi oleh konteks-konteks sosial dan politik khusus.

Kata Kunci: digital, media sosial, kharisma, politisi, Indonesia

1 Both writers are the main contributors who have an equal contribution to the writing of this paper 


\section{INTRODUCTION}

In February 2019, Ridwan Kamil, Governor of West Java, posted an unusual picture on his Instagram account. The picture is a montage of wedding invitation and screen captured conversation between Ridwan Kamil and one of his Instagram followers. The follower, a woman in her twenties, thanked Ridwan Kamil for giving her a matchmaking endorsement on Instagram² In that Instagram post, Ridwan Kamil mentioned her as someone looking for a husband. Apparently, another follower of Ridwan Kamil saw that post and started to contact the female follower and later even proposed marriage to her. The choice to perform matchmaking on social media account might be unusual for traditional politician. However, the action is normal for Ridwan Kamil. Aside from formal communication on policies, Ridwan Kamil occasionally publishes humorous and casual posts on his social media account, including playing as matchmaker. This persona on social media marks the emergence of new generation of politicians that are savvy enough to use social media as their strategic tool both to campaign and govern.

The role of media in paving and maintaining power among politicians in Indonesia is as old as the republic itself. Back in its early days of this republic, Soekarno conveyed powerful rhetoric, exploited radio to engage public in supporting his political programs. Likewise, Soeharto utilized TVRI (Television of the Republic of Indonesia) as one of the instrumental media to maintain his regime (Kitley, 1994). A decade after the dawn of New Order, Susilo Bambang Yudhoyono (SBY) and Wiranto felt the necessity to perform as a guest star in singing competition program, aired into millions of televisions all over Indonesia during the 2004 presidential candidacy. ${ }^{3}$ By

2 Gustiningsih, W. (2020). Saat Ridwan Kamil Menjadi Mak Comblang Lewat Instagram. lifestyle. Retrieved 13 April 2020, from https://www.cnbcindonesia.com/ lifestyle/20190203184534-33-53672/saat-ridwan-kamilmenjadi-mak-comblang-lewat-instagram. (accessed 13 April 2020)

3 detikNews. (2020). SBY Ikutan Nyanyi, AFI Jadi Ajang Kampanye Terselubung. detiknews. Retrieved 13 April 2020, from https://news.detik.com/berita/d-164959/ sby-ikutan-nyanyi-afi-jadi-ajang-kampanye-terselubung. (accessed 13 April 2020) participating in this popular competition, both politicians were hoping to be seen as a relatable figure to ordinary citizen. It is only natural, when the number of social media users in Indonesia is rising, many politicians would also use the same technology for political purpose.

The importance of social media in Indonesian politics came into the light in 2009, for there were two important events: massive rally against corruption, and 2009 presidential election. The mass rally was organized by Facebook users to support KPK (Corruption Eradication Commission), against Indonesian National Police that was perceived as corrupted institution. The rally was initiated from a Facebook group named 1.000.0000 Facebookers dukung Bibit-Chandra. The name of the group is taken from two board commissioners of KPK that people believed to be unfairly criminalized by the police. The cause gained a public momentum and has more members that the target of one million. Moreover, the continuous mass rally eventually became one consideration that made Indonesian police dropped the charges of those two KPK commissioners. For Indonesian public, including politicians, the movement thus became a precedent where online political cause could be mobilized to shape actual political outcomes beyond the network of Internet (Lim, 2013).

The second important event was the 2009 Indonesian presidential election. A year prior to this moment, Facebook has just become phenomenon in American politics. Barack Obama who came as an underdog, won Democratic Party presidential candidacy against Hillary Clinton, a much more established politician at that time. One of the key of his unexpected win was Obama's campaign strategy to exploit the organic supports from his Facebook group (Borah, 2016). He represented himself as the new hope in American politics through social media and later elected as the first African-American President of USA. The success story of Obama inspired Indonesian politicians to gain similar success in transforming social media support into electoral votes, including 2009 presidential candidates.

The 2009 Indonesian presidential election was a political moment where SBY aimed for 
his reelection as president. The competitors were Jusuf Kalla, an incumbent vice-president, and Megawati, former president of Indonesia. Each of these political camps utilized Facebook as part of their campaign strategy. Jusuf Kalla, tried to be the first democratically elected non-Javanese president, published the rhetoric questioning about the significance of ethnicity in Indonesian politics on his Facebook page (Widyawati, 2014). Implied in his article is expectation that the Javanese and non-Javanese cleavage, that is salient in Indonesian politics, would not be relevant anymore. Nevertheless, SBY, born and raised as Javanese won his second term presidency with a landslide margin.

While 2009 Indonesian presidential election marked the early use of social media, the incorporation of it into Indonesian politics is still superficial. The election and daily politics is still largely dominated by the conventional political machines (Mietzner, 2009). Nevertheless, it paves the way for the more strategic use of social media among Indonesian politicians. The emergence of figures such as Joko Widodo (Jokowi), Anies Baswedan, and Ridwan Kamil demonstrates the new wave of politicians that utilize social media as an integral part of their political campaign.

The utilization of social media in Indonesian politics were discussed in several previous research (e.g. Lim, 2017; Miichi, 2014; Aspinall, 2015). Nevertheless, there is still an absence of examination on how social media facilitates the rise of political leaders. In this regard, the article explores the topic with this following question: How do social media affordances enable politicians to manufacture political charisma? To what extent, political charisma developed on social media enabled politicians to influence their followers?

In this article we propose three arguments to solve the problems. First, social media affordances facilitate politicians to utilize multiple representations to construct political charisma. Prior to the existence of social media, the representation of politicians is contingent to the way media choose to portray the political figures. In consequence, apart from authoritarian regime, politicians could not have total controls in their public image. Social media bypassed this process and enable politicians to directly present and communicate their own narratives to public. In this regard, social media savvy politicians distinct themselves from ordinary politicians since they could tinker their own representations based on feedbacks from their online followers. This kind of utilization is even more relevant for figures like Ridwan Kamil whose life experiences embodied the image of modernity, associated with social media.

Second, the specificities of social media favor personalization of politics. On social media accounts, the online followers engaged more on personal contents. In consequence, the exposure of politician's personal life becomes integral on the construction of charisma on social media. Social media ecosystem is benefiting politicians that rely on personal charisma instead of formal political machinery. In this regards, social media politics has obscured the thin line between private and public politics even more.

Third, despite its significance, charisma developed within social media ecosystem is confined to specific social, cultural, and political contexts. As much as politicians try to represent themselves as a new blood in politics, in order to be elected, their charisma should not deviate much from the norms in society. Therefore, just as politics prior to social media, the programs proposed by politicians are still limited to the ones considered acceptable for mainstream prospective voters.

The article elaborates the issue in three parts. The first section discusses the role of media and the construction of charisma among political leaders. The second section will trace the political trajectory of Ridwan Kamil, in particular on how he utilizes social media to become one of the most important tools of political campaign. The last part will discuss how social media shapes the construction of political charisma and its future implications. The data in this article are based from numerous in-depth interviews, online observations on related social media platforms, and other relevant information derived from online news portals. 


\section{MEDIA AND THE FORMATION OF CHARISMA}

The discussion on charisma with its association to modern politics, owes from the proposition of this concept by Max Weber. At the time when Weber formulated the concept, charisma was positioned as a juxtaposed of modern rational bureaucracy (Adair-Toteff, 2005). Charismatic leadership, in Weber's argument is one among the three forms of legitimate authority, the other two would be: traditionalist and rational (Hughes-Freeland 2007, 178). Traditional authority, in his point of view, is the legitimacy sustained by the continuation of tradition. Rational authority on the other hand, is based on the rational legal framework. While it seems to be different, both of both of these authorities have similarities in which both are stable authorities that are continuously reinforced by routinization (Adair-Toteff 2005, 190). The necessity of routinization implicates that both rational and traditional authority derives their legitimacy from some sort of institution. Unlike these two forms of authority, charismatic authority relies on certain quality that is attached to individuals. Moreover, Weber described it as irrational phenomenon that only occurs on the time of crisis (Weber, 1946).

The portrayal was inevitable, since the conception of charisma is derived from religious concept (Adair-Toteff 2005, 195) that does not share many characteristics with the ideal of rational bureaucracy. As the consequence, later the concept is common to be attached to political leaders whose prominences rise at the time of crises. During World War II, the term of charismatic leadership was often used to describe both Adolf Hitler and Winston Churchill, regardless on each other's respective political position (Aberbach, 1996). For similar reason, the term charisma was also applied for influential leaders like Sukarno in Indonesia (Anderson, 1990b) for his ability to mobilize mass of people on the period of turmoil.

One crucial trait of Weber's charismatic leader is the quality of extraordinariness that differentiate the leader from commoner (Derman, 2012). The description of political leaders in this context is not that different from holy man or prophet in many religions around the world, which were chosen by God, and attracted number of followers. Yet, at the same time the influence of charismatic leaders is contingent to the perception from their followers. Despite supposed to be attached to individual quality, once the leader lost the impression of being extraordinary, the leader no longer has the charismatic appeals anymore (Derman, 2012, 181). Therefore, this transient characteristic of charisma would eventually made leader need routinization to maintain their authority (Weber, 1947, 164). Should we apply this framework into the contemporary political leaders, it is then equally important to observe the reproduction of authority from charismatic leaders even after the election.

Since its formulation, the charisma as proposed by Weber has been criticized for many reasons. One of the most important critics came from Benedict Anderson's Javanese conception of power as the counter argument. The ideal characteristic that Weber posited could not be easily accepted universally, due to the European bias. In Weber's description for instance, charismatic leadership is temporary situation that will eventually stabilized into legal rational authority. This proposition is contradictory to Javanese concept of power, which perceive charisma as an embedded aspect for leadership (Anderson 1990, 76). In consequence, it is almost impossible for Javanese people to imagine the existence of leaders without charisma. Parallel to Weber's model of charismatic leader, Javanese leaders are also perceived to have personal quality that becomes the source of the authority (Anderson 1990, 76). Nonetheless, the attachment of charisma to leaders does not mean that the authority to be unlimited. Conversely, the charismatic quality of leaders is limited to the judgments of its subject. Therefore, the influence of charismatic leaders is bounded to particular geographic, historical, and cultural contexts (Anderson 1990a, 78). The awareness of such a limit is important to remember since contemporary construction of charisma we presume is also attached to similar constraints.

The notion of charisma also gained another traction when scholars discussed the concept of celebrity. As pointed out by Hughes-Freeland 
(2007), contemporary phenomenon of celebrity shared characteristics with the concept of charisma. Both concepts addressed subjects that are perceived to have inner quality that able to influence large number of followers. Nevertheless, drawing from studies on celebrity (Marshall, 1997; Rojek, 2001), there are some contemporary elements on the notion of celebrity that slightly differs the concept from the classic ideals of charisma (Hughes-Freeland 2007, 180-182). One of the crucial aspects is the role of media to manufacture the persona of celebrity. Another essential aspect is 'affective rationality' (Marshall, 1997, 75) that helps celebrity maintain their capability to influence their followers. Should we take the proposition that celebrity is a new form of 'objectified charisma' (Hughes-Freeland 2007, 193), it is then possible that affective elements play some role on the construction of charisma on social media.

Apart from the debates on the notion of celebrity, the recent rise of populism has also brought the discussion of charisma back at the forefront. All around the world, the proliferation of populist politics is almost inseparable with charismatic figures that have capabilities to mobilize mass, particularly from grassroots voters. In Brazil there is Bolsonaro (Hunter \& Power, 2019), there is also Donald Trump in the US (Norris \& Inglehart, 2019), and even Prabowo Subianto and Jokowi in Indonesia could also be referred as populist to some extent (Aspinall, 2015). While there is not any single definitive definition on populism (Kenny, 2019) many scholars would agree that mobilizational capacity is one among several key attributes phenomenon that would usually be assigned as populism. Aforementioned populist leaders in this regard, have employed charismatic traits as one of their most crucial tools in contesting established political institutions on many respective areas. In this regard, while populism do not necessarily always has charismatic leaders (Mudde \& Kaltwasse, 2014), the populist aspect associated with charismatic leaders could not be overlooked.

On the discussion of social media within Indonesian politics, there was plenty of previous research that briefly touches the subject. Back in the 2009 Presidential Election, candidates utilized Facebook with little expectations to emulate the success of Barack Obama in the the US (Widyawati, 2014). During the Special Capital Region of Jakarta (DKI Jakarta) governor election in 2012, both supporters of Jokowi and Fauzi Bowo disseminated their campaign on social media and messaging application (Miichi, 2014). The use of social media was also part of Jokowi's victory in 2014, albeit that it was just one variables of his success (Mietzner, 2014). Even his opposition, Prabowo Subianto also employed social media campaign to provide his followers more direct access toward his ideals on Indonesia as a nation (Aspinall, 2015). Nonetheless, there are not many careful examinations on how the social media facilitated the formation of charisma of these leaders.

One explanation for this academic lacuna might lies from premature ecosystem of social media in the past. Since social media use was relatively a new phenomenon, politicians had not found a way apart from experimentations to actually integrate the social media into strategic tools for campaign. The other reason that that might also contribute to the literature gap might be the general wariness among scholars not to exaggerate the impact of social media on political and social issues. Particularly, because the role of social media has been lauded by media outlets as the foundation behind large political movement such as Arab Spring or Occupy Wallstreet. It is then understandable to see how scholar put some caveats on the potentials of social media as a medium of politics (Fuady, 2018; Hadi, 2018; Lim, 2013)the gap of rural-urban internet access remains a great challenge. As reported in the 2016 Information and Communication Technology (ICT). Nevertheless, that does not mean that we should neglect the examination of social media in contemporary politics. If anything, the issue has been more relevant in the past few years. In 2019 , it is estimated that Indonesia has around 130 million Facebook users and 62 million members of Instagram (Hootsuite, 2019). The large number of constituents has driven even the smallest politicians in contemporary Indonesia to reach out for potential voters on social media. In this regard, it is crucial to gain comprehension 
Table. 1 Comparison Table of Indonesian Politicians' Social Media

\begin{tabular}{lllll}
\hline Indonesian Politicians & $\begin{array}{l}\text { Instagram } \\
\text { (followers) }\end{array}$ & $\begin{array}{l}\text { Facebook } \\
\text { (likes) }\end{array}$ & $\begin{array}{l}\text { Twitter } \\
\text { (followers) }\end{array}$ & Total Population $^{\mathbf{5}}$ \\
$\begin{array}{l}\text { Joko Widodo } \\
\text { (President of Indonesia) }\end{array}$ & $35.7 \mathrm{M}$ & $9.9 \mathrm{M}$ & $14.4 \mathrm{M}$ & $268 \mathrm{M}$ \\
\hline $\begin{array}{l}\text { Ridwan Kamil } \\
\text { (West Java Governor) }\end{array}$ & $12.9 \mathrm{M}$ & $3.4 \mathrm{M}$ & $4.1 \mathrm{M}$ & $49.3 \mathrm{M}$ \\
\hline $\begin{array}{l}\text { Anies Baswedan } \\
\text { (Jakarta Governor) }\end{array}$ & $4.6 \mathrm{M}$ & $1.7 \mathrm{M}$ & $3.8 \mathrm{M}$ & $10.5 \mathrm{M}$ \\
\hline $\begin{array}{l}\text { Ganjar Pranowo } \\
\text { (Central Java Governor) }\end{array}$ & $3.1 \mathrm{M}$ & $726 \mathrm{~K}$ & $1.6 \mathrm{M}$ & $34.7 \mathrm{M}$ \\
\hline $\begin{array}{l}\text { Khofifah Indar Parawansa } \\
\text { (East Java Governor) }\end{array}$ & $791.7 \mathrm{~K}$ & $123 \mathrm{~K}$ & $515.2 \mathrm{~K}$ & $39.6 \mathrm{M}$ \\
\hline $\begin{array}{l}\text { Wahidin Halim } \\
\text { (Banten Governor) }\end{array}$ & $52.3 \mathrm{~K}$ & $25 \mathrm{~K}$ & 465 & $12.9 \mathrm{M}$ \\
\hline
\end{tabular}

Source: Official social media of politicians (per September 2020) and BPS

on how social media plays role in the formation of charisma among politicians. Against these backgrounds, the next chapter will examine the issue of charisma development on social media through the case of Ridwan Kamil, charismatic figure from West Java whose political careers is inseparable from his persona on this technology.

\section{MANUFACTURING POLITICAL CHARISMA ON SOCIAL MEDIA}

Ridwan Kamil, the $15^{\text {th }}$ Governor of West Java Province, began his term on September 2018. Previously, from 2013 to 2018, he was the Mayor of Bandung City, capital of West Java. Born in Bandung, Ridwan Kamil was a wellknown architect who attended the Department of Architecture, Bandung Institute of Technology in 1990, and had his Master of Urban Design at the College of Environmental Design, University of California, Berkeley in 1999. In 2004, Kamil founded Urbane Indonesia, an architecture, urban design and project visioning consultant firm. Ridwan Kamil is also a winner of the British Council's Young Creative Entrepreneur Award in 2006 and Architect of the Year 2009 in Elle Décor Magazine. In Indonesia, Ridwan Kamil is also known for his contribution in various architectural projects, including Indonesia Berkebun, Aceh Tsunami Museum in Indonesia, Marina Bay Waterfront Master Plan in Singapore, Sukhothai Urban Resort Master Plan in Thailand, Beijing
CBD Master Plan in China, and Ras Al Kaimah Waterfront in Qatar. ${ }^{4}$

His expressive, humorous, and up-to-date post on social media has made Ridwan Kamil one of the most popular politicians in Indonesia. In comparison with other regional leaders that lead the most populous regions in Indonesia, Ridwan Kamil easily surpassed his counterparts. In September 2020, he has 12.9 Instagram followers, 3.4 million likes on Facebook page, and 4.1 millions of Twitter followers. Among other Indonesian politicians, these numbers are only second to Joko Widodo, the president of Indonesia. This level of outreach on social media platforms made Ridwan Kamil an ideal figure for a study that aims to comprehend the ties between social media platform and contemporary political charisma.

\section{Bandung Mayoral Election}

Ridwan Kamil began his political career in 2013 when he entered Bandung election race together with Oded Muhammad Danial, nominated by the Justice Prosperous Party (PKS) and the Great Indonesian Movement Party (Gerindra).

4 Leong, K., \& Leong, C. (2015). EAROPH-Australia eBulletin [Ebook]. Retrieved January 2015, from http:// www.earophaustralia.com/uploads/5/5/3/3/5533406/ earoph-a_ebulletin_jan2015_issue_-reducedl_070115. pdf.

5 Statistik Indonesia 2020, BPS, April 2020, https://www.bps.go.id/publication/2020/04/29/ e9011b3155d45d70823c141f/statistik-indonesia-2020. html 

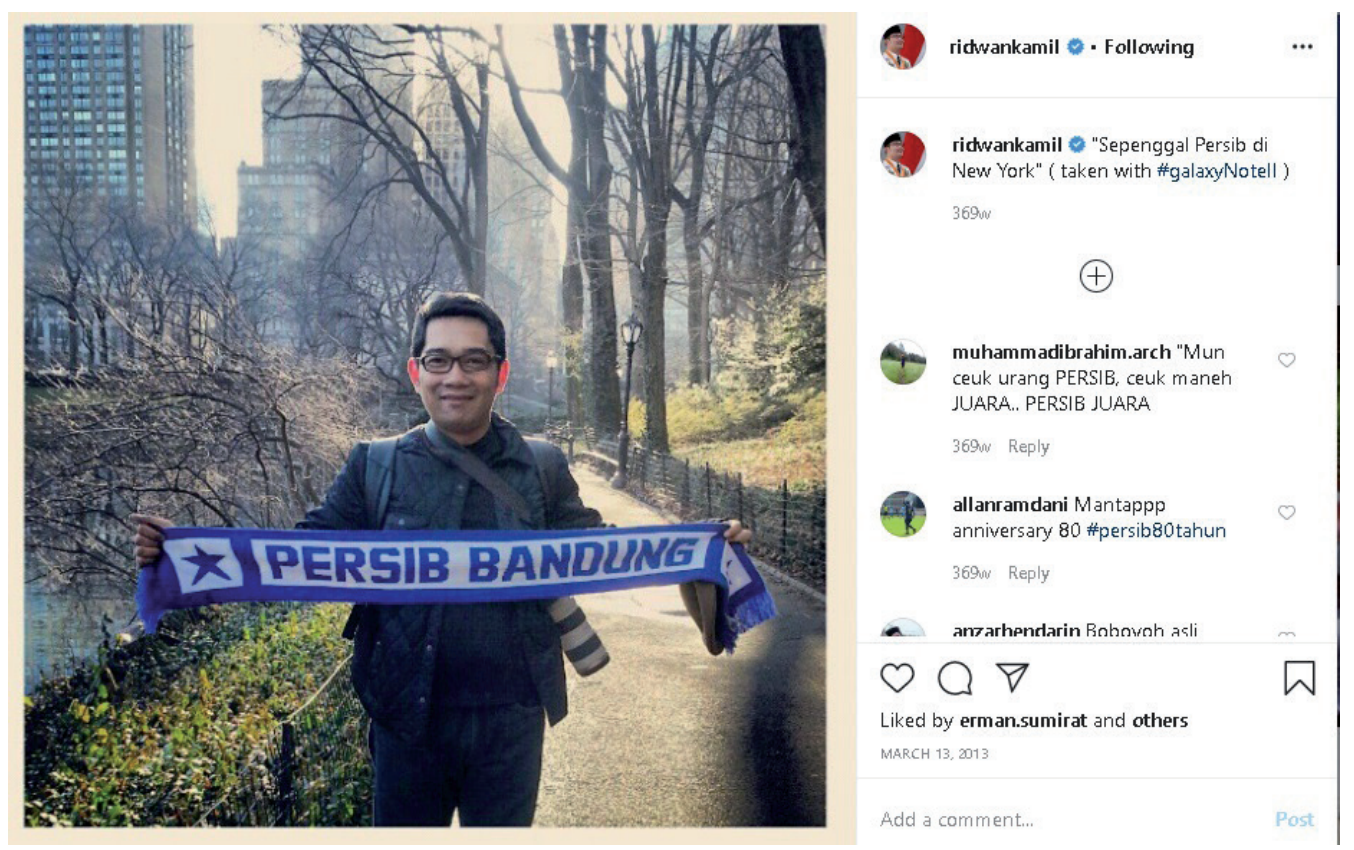

Picture 1. Ridwan Kamil and Persib Bandung football club (12 March 2013)

At first, Ridwan Kamil admitted that he never thought about joining politics. However, eight months prior to the election, he was asked to run as mayor by community groups and his former students from Bandung Institute of Technology, where he worked as a lecturer. ${ }^{6}$ He stated, "The city is in ruins. While 17 years of my life have been dedicated to fixing other people's cities, I feel very uncomfortable seeing my home town like this." 7

At the beginning of his nomination, Jaringan Survey Inisiatif (JSI) found that candidates Ayi Vivananda and Nani Suryani, who were nominated by Indonesian Democratic Party of Struggle (PDIP) and the National Mandate Party (PAN), had the highest number of popularity; with more than 60 percent Bandung citizen was familiar with this political couple. ${ }^{8}$ As an unseeded candidate, Ridwan Kamil's victory in Bandung city election were considered surprising. Among the key of their victory was Ridwan-Oded ability

6 Bland, B. (2013). Architect Ridwan Kamil, the new face of Indonesian politics. Ft.com. Retrieved 20 April 2020, from https://www.ft.com/content/ a69e276e-0a6d-11e3-9cec-00144feabdc0.

7 Ibid.

8 Dipa, A. (2013). Poor turnout leaves Ridwan-Oded leading Bandung mayoral race. The Jakarta Post. Retrieved 27 April 2020, from https://www.thejakartapost.com/ news/2013/06/24/poor-turnout-leaves-ridwan-odedleading-bandung-mayoral-race.html. to represent themselves as the amalgamation of religious, family man, youthful, and modern professional figure. During the period of campaign, Ridwan-Oded often wore Muslim dress, spoke politely, and avoided from criticizing or insulting other candidates. These representations are in line with the characteristic of voters in Bandung that also identify as religious and well-informed. ${ }^{9}$

Among the fundamental key of his campaign in 2013 city election was the utilization of Twitter. The social media platform was crucial in the transformation of Ridwan Kamil who was once a respected architect into the strongest candidate in relatively short time (Iqbal, 2016). The selection of Twitter social media was strategic since Bandung was the sixth city with the most active Twitter users in the world in 2013. ${ }^{10}$ Moreover, aside from Ridwan Kamil personal Twitter account,@RidwanKamil, his team also has@ $\mathrm{RKBgd}$ account that functioned as a centre of

9 Mawardi, I. (2017). Inilah Strategi yang Perlu Diterapkan Calon Wali Kota Bandung Agar Dipilih di Pilwalkot 2018 - Tribun Jabar. Tribun Jabar. Retrieved 27 April 2020, from https://jabar.tribunnews.com/2017/10/20/ inilah-strategi-yang-perlu-diterapkan-calon-wali-kotabandung-agar-dipilih-di-pilwalkot-2018.

10 Tempo.co. (2013). Jakarta dan Bandung 10 Besar Kota Teriuh Twitter. Tempo. Retrieved 27 April 2020, from https://tekno.tempo.co/read/451350/jakarta-danbandung-10-besar-kota-teriuh-twitter. 
information and space aim to to persuade voters on Ridwan's political ideas.

Even prior to 2013 Bandung mayoral election, Ridwan Kamil was already active on social media, especially Twitter and Facebook, and later Instagram. His social media accounts are not only presenting work-related contents, but also for personal activities such as family, hobbies and jokes. On Ridwan Kamil's Instagram during period of the nomination to the campaign (March-June 2013) we found there were at least four categories of posts uploaded, which were: 1) as a prospective leaders, marked by posts about his contribution to Bandung residents, 2) displaying a figure as a family man (as husband, father, and devoted son), 3) his Bandung's identity through his fondness for Persib Bandung football club, and 4) as an obedient Muslims through his post kiyai (Islamic leaders) and umrah before the elections. These four representations were Ridwan Kamil's early foundation of political charisma.

Aside from the representation, the ability to perform as key person in time of crisis is also a necessary trait in developing political charisma in social media. One important issue that Ridwan Kamil pressed during election was environmental issues, such as his participation in Aksi Siliwangi Ngababakan Deui on May 21, 2013. ${ }^{11}$ The rally was the culmination of protests from Bandung citizen, against the plan of the incumbent mayor Dada Rosada, to commercialize Babakan Siliwangi City Forest. Simultaneously with mobilization on street, the protest was also getting online traction through petition on Change. org that had more than 7,900 signatures. The issue gained more attention with support from alliances of many influential figures and community such as Acil Bimbo, Harry Pocang, Walhi Jabar, Paguyuban Pasundan, Common Room, and Bandung Creative City Forum. Against this backdrop, Ridwan Kamil participation in this cause has catapulted his popularity in the 2013 Bandung election. The popularity in particular, owes to Kamil's position as the head of Bandung

11 Kurniawan, T. (2013). Ribuan Warga Kecam Wali Kota Bandung Lewat Petisi dan Aksi. beritasatu.com. Retrieved 29 April 2020, from https://www.beritasatu. com/beritasatu/nasional/115060/ribuan-warga-kecamwali-kota-bandung-lewat-petisi-dan-aksi.
Creative City Forum that plays significant role on the rally.

One of Ridwan Kamil's keys of social media campaign, lies in the way he specifically designed social media communication for each group of targeted voters. For young generations, as usually dubbed as millennials ${ }^{12}$ by Indonesian politicians and media, Ridwan Kamil represents himself as a leader who understands the aspiration of youth. As he explained after Ridwan Kamil elected, ${ }^{13}$ "I am a social media user who became a mayor. (I am) just like you who actively using social media." ${ }^{14}$

On the other hand, to reach out to nonmillennial voters, Ridwan Kamil relied on other means of media, he appeared as a guest on infotainment and talkshows such as Kick Andy 'Sharing for Others' on Metro TV ${ }^{15}$ and TVRI Profile West Java. ${ }^{16}$ Even after being elected, he maintains his popularity by appearing as a guest star on television shows like Sudut Pandang ${ }^{17}$ with Fifi Aleyda Yahya on Metro TV, Ini Talkshow $^{18}$ on NET TV (2014), and EXCLUSIVE 1 Hour with Ridwan Kamil Mayor of Bandung ${ }^{19}$ on RTV (2015).

12 The term millenial were suggested by American demographer referrint to those who were born 1980s to the end of 1990 s, citizen that were born after that period is classfified as generation $\mathrm{Z}$.

13 Wiyono, A. (2016). Ridwan Kamil: Saya anak sosmed yang jadi wali kota | merdeka.com. merdeka.com. Retrieved 27 May 2020, from https://www.merdeka. com/peristiwa/ridwan-kamil-saya-anak-sosmed-yangjadi-wali-kota.html.

14 Original version in Indonesian language: "Saya ini anak sosial media yang jadi wali kota. Sama seperti kalian yang memang aktif menggunakan media sosial,"

15 indonesiaproud. (2013). Ridwan Kamil di Kick Andy: Berbagi Demi Sesama 2 [Video]. Retrieved 18 June 2020, from https://www.youtube.com/watch? $\mathrm{v}=\mathrm{Itq}$ IBrSLK4.

16 Pandumudita, P. (2013). Ridwan Kamil di TVRI acara Profile 22 Maret 2013 [Video]. Retrieved 18 June 2020, from https://www.youtube.com/watch?v=7DUGx1XijA.

17 Metrotvnews. (2013). Sudut Pandang: Ridwan Kamil Part 1 [Video]. Retrieved 18 June 2020, from https:// www.youtube.com/watch?v=HOjLzV1DtK4.

18 Show, I. T. (2013). Ini Talk Show Pemimpin Part 1/4 - Ridwan Kamil, Budi Cilok, Eddi Brokoli, Karinding Attack [Video]. Retrieved 18 June 2020, from https:// www.youtube.com/watch?v=gyBA70mz1hA.

19 RTV. (2013). Satu Jam Bersama Ridwan Kamil dengan Cheryl Tanzil - RTV [Video]. Retrieved 


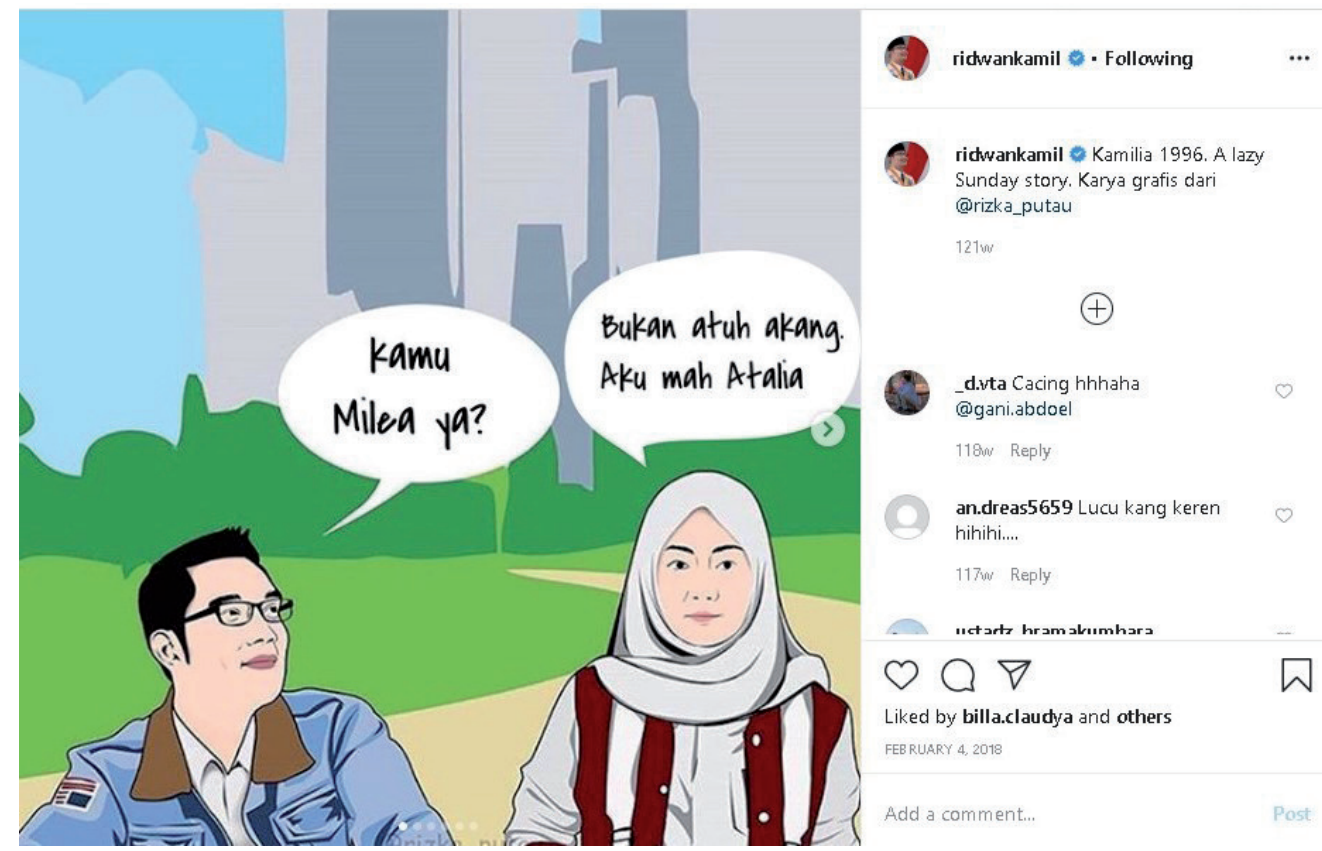

Picture 2. Parodied meme of Dilan 1990 film posted by Ridwan Kamil (4 February 2018)

Similar awareness to design the campaign is also relevant to the classification of regions in Bandung. During campaign, Ridwan Kamil adjusted his communication style to suit the character of the people in each specific region. "Bandung's educated people are mostly in the north, so on my campaign I will speak like a professor. Meanwhile, in the southern area I will speak broken Indonesian (bahasa pasar) ${ }^{20}$," as stated by Ridwan Kamil. ${ }^{21}$

The ability to convey charisma both offline and online interactions made Ridwan Kamil popularity risen through the campaign. In consequence, despite started as the least popular candidate, Ridwan Kamil became the most preferred figure with a score of 30.4 percent in the survey of Bandung Mayor candidate figures conducted by LPPM Padjadjaran University. ${ }^{22}$

18 June 2020, from https://www.youtube.com/ watch? $=$ DnZqo0rUlqU.

20 Original version in Indonesian language: "Orang-orang pintar Bandung kebanyakan di utara, maka kampanye saya bahasanya kayak profesor, ya. Kalau di wilayah selatan bahasa pasar,"

21 Siswadi, A. (2015, October 9). Pilkada Serentak, Begini Strategi Kampanye Ridwan Kamil. Tempo. Retrieved 27 May 2020, from https://nasional.tempo. $\mathrm{co} / \mathrm{read} / 707963 /$ pilkada-serentak-begini-strategikampanye-ridwan-kamil

22 Galih, P. (2013, June 18). Figur Ridwan Kamil Disukai Pemilih Bandung. Tempo. Retrieved 28 May 2020, from
The same research also confirmed that voters in Bandung valued the candidate figures more than the party who nominated them. Ridwan Kamil and his partner, Oded Danial then won an election with sounding victory after being able to secured $45.24 \%$ number of votes. ${ }^{23}$

\section{Online Governance of Ridwan Kamil}

The utilization of social media did not stop when Ridwan Kamil was appointed as the mayor of Bandung. On contrary, social media eventually play significant role on the way he governs Bandung. Ridwan Kamil, after all, believes that the perception of public officials should not tweeting is an old paradigm because currently we are living in the era where information can be obtained from various ways. ${ }^{24}$ It is also his way to connect to younger demographic group in Bandung.

https://nasional.tempo.co/read/489307/figur-ridwankamil-disukai-pemilih-bandung

23 Kuswandi, R. (2013, June 28). Ridwan Kamil Wali Kota Terpilih Bandung. KOMPAS.Com. Retrieved 15 June 2020, from https://regional.kompas.com/ $\mathrm{read} / 2013 / 06 / 28 / 1618054 /$ Ridwan.Kamil.Wali.Kota. Terpilih.Bandung

24 Wiyono, A. (2016, February 27). Ridwan Kamil: Saya anak sosmed yang jadi wali kota. Merdeka.Com. Retrieved 27 May 2020, from https://www.merdeka. com/peristiwa/ridwan-kamil-saya-anak-sosmed-yangjadi-wali-kota.html 

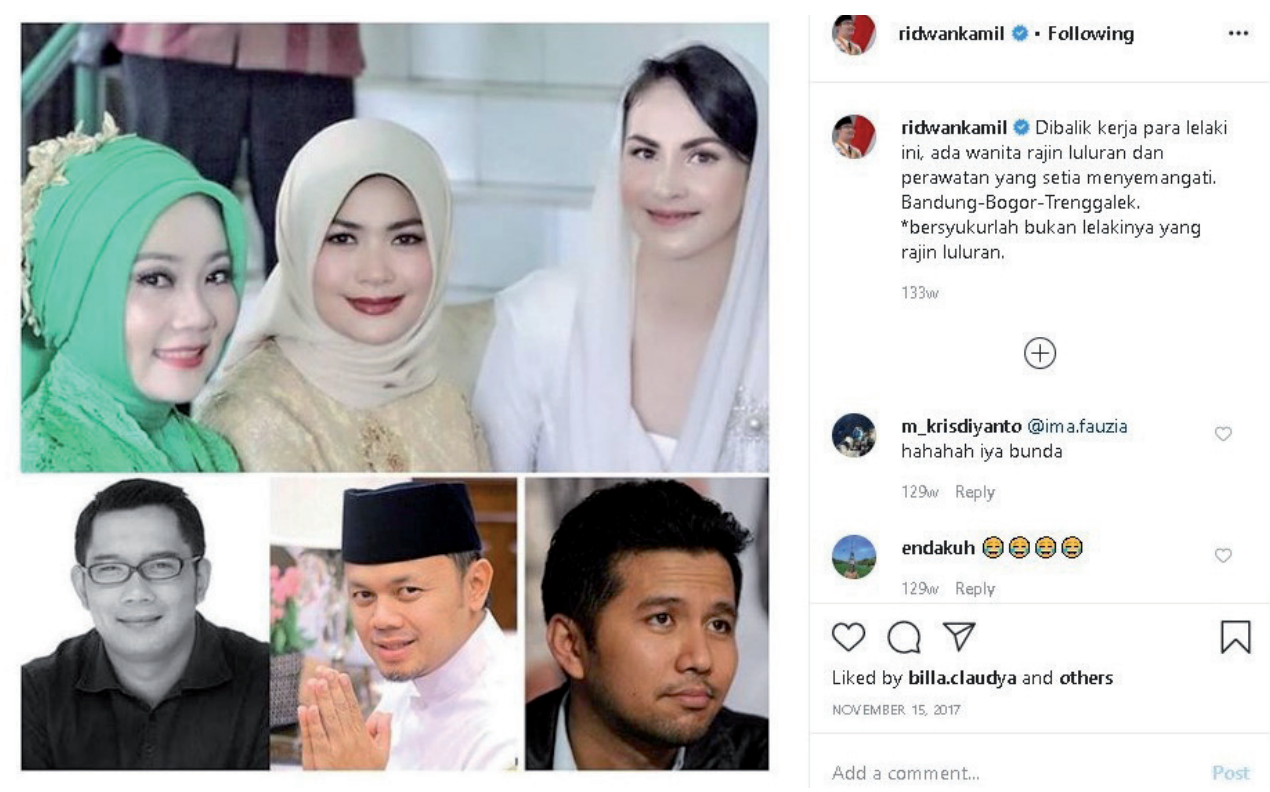

Picture 3. Ridwan Kamil's post on the role of woman (15 November 2017)

The appeal toward younger voters has always been one of the most important characteristics of Ridwan Kamil's charisma. He for instance, does not hesitate to appropriate popular culture products into his social media account. When Dilan 1990, a teenlit film sets in Bandung became very popular nationally, Ridwan Kamil used it as a reference for his social media contents. At the same time, his followers are already familiar with Ridwan Kamil's association to popular cultures, thus they also often created creative contents presenting Ridwan Kamil in various creative mediums such as comic or meme. Their existence thus provided the mayor of Bandung with more contents that also maintain his fun and relatable image.

Despite fully realizing those young voters are crucial group that became the foundation of his charisma, that does not mean the interaction between Ridwan Kamil and his followers to be inauthentic. Rather, as stated by Arfi Rafnialdi, ${ }^{25}$ Kamil's social media follower interactions are organic because they are real human users. Ridwan Kamil's expressive style in this regard thus shaped by interactions and eventually also to his personality. As consequence, Ridwan Kamil ability to communicate well and in harmony

25 Arfi Rafnialdi was Ridwan Kamil's advisor during Bandung mayoral and West Java Gubernatorial election. Currently, he serves as Ridwan's public policy expert and the daily chairman of the West Java Development Acceleration Team with language styles used among the youth, made young followers saw Ridwan Kamil as a representation of their leaders.

“What's interesting about Kang Emil's (Ridwan's nickname) social media interaction is, it is an organic interaction, not built by bots ... Kang Emil is more expressive. Because from the beginning it was embedded in him. Kang Emil's style of communication is like that, connect with the Millennial. This is why Millennial feel Kang Emil as a representation of the leaders of their generation. " ${ }^{26}$ (interview with Arfi, 26 April 2018, in Bandung)

Despite Ridwan Kamil's ability to develop charisma as a fun tech-savvy leader, he still gets criticism about his social media contents. In particular, was his tendency of sexism toward woman and discrimination to LGBT community. The criticism on LGBT was raised when as mayor of Bandung, Ridwan Kamil uploaded a photo of a Thailand celebrity named Punpun Sutatta Udomsilp. Alongside the Instagram post, Ridwan Kamil also made humorous remarks, "Greetings from Thai artists. Hopefully she is not a man. ${ }^{27}$ " His

26 Original version in Indonesian language: "Yang menarik dari interaksi medsos kang emil, itu interaksi organik, bukan dibangun oleh bot... Kalau kang emil dia lebih ekspresif. Karena memang dari awal itu embedded dalam dirinya. Kang emil ini memang gaya interaksi komunikasinya begitu, nyambung bahasanya dengan milenial. Inilah kenapa kelompok milenial merasa kang emil sebagai representasi pemimpin generasinya."

27 Original version in Indonesian language: "Dapat salam dari artis Thailand. Semoga ia bukan lelaki." 
remarks considered harmful since it reproduced the stigma long suffered by LGBT community in Indonesia. ${ }^{28}$

On the case of sexism, Ridwan Kamil once uploaded a photo of his wife, Atalia Praratya, alongside with Bima Arya Sugiarto's (Mayor of Bogor) wife named Yane Ardian, and Arumi Bachsin, the wife of Emil Dardak (Regeant of Trenggalek). Under the picture Ridwan Kamil made a caption, "Behind the work of these men, there are women who diligently took care of their body with scrubs and skincare routine that faithfully support (their husband). BandungBogor-Trenggalek *be thankful it is not (us) the man who diligently scrubs". ${ }^{29}$ This caption received backlash since it considered to reinforce the patriarchic notion that women only exist to support the work of men in public arena.

Ridwan Kamil later claimed that his controversial captions had no specific intention. ${ }^{30}$ According to Ridwan Kamil, the caption he made was interpreted and read differently. He admitted that each problem has contextual value, a particular issue that can be considered as sensitive matters in Indonesia. However, the implication of this kind of caption still triggered a debate on the kind of leadership Ridwan Kamil represents in social media.

Despite the various pros and cons on his social media activities, a survey conducted by the Indonesia Strategic Institute (Instrat) showed that 80 percent of the 500 public respondents in Bandung claimed to be satisfied with RidwanOded performance. ${ }^{31}$ In addition, 86 percent respondents considered Bandung has changed for

28 Kirnandita, P. (2017, November 28). Di Balik KomentarKomentar Post Instagram Ridwan Kamil. Tirto.Id. Retrieved 28 May 2020, from https://tirto.id/di-balikkomentar-komentar-post-instagram-ridwan-kamil-cAN2

29 Original version in Indonesian language: "Dibalik kerja para lelaki ini, ada wanita rajin luluran dan perawatan yang setia menyemangati. Bandung-Bogor-Trenggalek. *bersyukurlah bukan lelakinya yang rajin luluran."

30 BBC News Indonesia. (2018, January 9). Ridwan Kamil dan strategi media sosialnya: Kenapa selalu soal jomblo?. Retrieved 28 May 2020, from https://www.bbc. com/indonesia/trensosial-42319886

31 Mauludy, M. F. (2017, October 16). Warga Kota Bandung Masih Galau Pilih Pengganti Ridwan Kamil. Pikiran-Rakyat.Com. Retrived 28 May 2020, from https://www.pikiran-rakyat.com/bandung-raya/ the better. Ridwan Kamil after all, did not just rely on his personal social media account to govern Bandung. He also believes that technological form of governance should be implemented by his bureaucracy. Initially, when Ridwan Kamil started his position as mayor, the city government was not active on social media. Under his leadership, there are 20 offices, 30 sub-districts, and 151 urban villages in Bandung that now have Twitter account which regularly post news and photos of activities at least once a day. ${ }^{32}$

According to Ridwan Kamil, the use of social media for officials such as heads of offices, sub-district heads, and village heads provides at least three benefits. First, as a control function that can save the state budget up to Rp1 trillion. Second, as an observation tool before making important decisions. Third, as a means of communication with the community. ${ }^{33}$ Being active on social media, using casual and friendly language is important to increase public trust level for government. 'If we 'jaim' (concerned about one's image) and stingy to share information, it will actually decrease people's trust, ${ }^{34}$ ", as stated the mayor.

Apart from social media, Ridwan Kamil also introduced a number of technological innovations for Bandung government. Under his leadership, Bandung for instance introduced e-musrenbang ${ }^{35}$, an Internet mediated platform that meant to grasp the grass roots aspiration of Bandung citizen. The mayor also introduced SIP Bandung Juara $^{36}$, assessment information system

pr-01287643/warga-kota-bandung-masih-galau-pilihpengganti-ridwan-kamil-411648

32 Berita KSP. (2017, January 28). Kiat Bermedsos Cerdas ala Ridwan Kamil. Ksp.Go.Id. Retrived 27 May 2020, from https://www.ksp.go.id/kiat-bermedsos-cerdas-alaridwan-kamil.htm

33 Ibid.

34 Original version in Indonesian language: "Kalau kita 'jaim' dan pelit berbagi informasi, justru kepercayaan orang jadi turun,"

35 Maulana, A. G. (2017, February 2). Bandung | Pemkot Bandung Luncurkan E-Musrenbang. Ayobandung.Com. Retrieved 18 June 2020, from https://ayobandung.com/ $\mathrm{read} / 2017 / 02 / 02 / 15931 /$ pemkot-bandung-luncurkan-emusrenbang

36 Ispranoto, T. (2018, August 1). Oded Siap Sempurnakan Bandung Juara Era Ridwan Kamil. Detiknews. Retrieved 18 June 2020, from https://news.detik.com/berita-jawa- 
Table 2. Comparison Table of Social Media of 2018 West Java Gubernatorial Elections Participants

\begin{tabular}{llll}
$\begin{array}{l}\text { West Java Gubernatorial Elec- } \\
\text { tions Participants }\end{array}$ & $\begin{array}{l}\text { Instagram } \\
\text { (followers) }\end{array}$ & $\begin{array}{l}\text { Facebook } \\
\text { (likes) }\end{array}$ & $\begin{array}{l}\text { Twitter } \\
\text { (followers) }\end{array}$ \\
\hline Ridwan Kamil & $12.9 \mathrm{M}$ & $3.4 \mathrm{M}$ & $4.1 \mathrm{M}$ \\
\hline Deddy Mizwar & $221.3 \mathrm{~K}$ & $698 \mathrm{~K}$ & 318 \\
\hline Mayjen Sudrajat & $34.8 \mathrm{~K}$ & $150 \mathrm{~K}$ & $16.5 \mathrm{~K}$ \\
\hline Tubagus Hasanuddin & $5.4 \mathrm{~K}$ & $3.5 \mathrm{~K}$ & $3.8 \mathrm{~K}$ \\
\hline
\end{tabular}

Source: Official politician social media (per September 2020)

that could be used by Bandung citizen to evaluate their public officials. Regardless, to the actual effectiveness of such programs, the introduction of technology within his governance thus reinforced Ridwan Kamil's charismas as the modern tech-savvy leaders. These achievements became the motivation that drive Ridwan Kamil to take a larger political seat as governor in West Java, while leaving Oded to be his successor as Mayor in Bandung.

\section{West Java Governor's Election}

During the 2018 West Java Governor election, Ridwan Kamil also used his Instagram account @ RidwanKamil to promote his candidacy. Ridwan Kamil, started his campaign for the seat of Governor in a different way than when he started his political career in Bandung. In West Java, Ridwan Kamil had already a high electability due to a positive image among middle class youth. ${ }^{37}$ At this point, Ridwan Kamil and his team are aware that one of his strengths is his utilization of social media. He believes that social media is the easiest way to reach many people in comparison to television and radio which require more time and money. ${ }^{38}$

We are not able to provide the social media data in times of election, yet even the current data demonstrates the dominance of Ridwan Kamil on

barat/d-4144948/oded-siap-sempurnakan-bandung-juaraera-ridwan-kamil

37 Firdaus, R. F. (2017, December 28). Sering main media sosial, Ridwan Kamil mampu pikat generasi millenial. Merdeka.Com. Retrieved 27 May 2020, from https:// www.merdeka.com/politik/sering-main-media-sosialridwan-kamil-mampu-pikat-generasi-millenial.html

38 BBC News Indonesia. (2018, January 9). Ridwan Kamil dan strategi media sosialnya: Kenapa selalu soal jomblo? Retrieved 28 May 2020, from https://www.bbc. com/indonesia/trensosial-42319886 social media. While Ridwan Kamil is currently followed by 12.9 million followers on Instagram, Deddy Mizwar the second most popular candidate, is only followed by around 221 thousand followers. In fact, should we add the followers from the two other candidates as well, the added numbers still not reach one tenth of Ridwan Kamil's followers. The stark difference between Ridwan Kamil and other candidates is also relevant on other platform such as Facebook and Twitter. These numbers show how social media is much more integral to Ridwan Kamil's political campaign in comparison to his competitors.

On social media, Ridwan Kamil often makes funny jokes when replying to his followers' comments, this makes followers feel familiar and close with him. In addition, Ridwan Kamil also often made an appearance as a cameo in sinetron (Indonesia soap operas) and films, especially those located in Bandung such as Preman Pensiun and Dilan 1990. Therefore, Ridwan Kamil did not need to build a social network from scratch since he has invested it for a long time, particularly to young voters. The capability to communicate with younger generation is crucial, particularly because as Ridwan Kamil mentioned ${ }^{39}$, that from nearly 50 million West Java citizens, almost half categorized as millennial and generation $\mathrm{Z}$. This age group are also the ones that is most familiar with social media in comparison to previous generation. As reported by several research, the Internet use of among millennial is the largest percentage with age group 15-19 years (91\%), 20-24 years $(88.5 \%)$, and $25-29$ years $(82.7 \%)$ (APJII, 2019). Meanwhile NapoleonCat reported

39 Rezkisari, I. (2019, February 21). Ridwan Kamil Ungkap Alasannya Humoris di Media Sosial. Republika Online. Retrieved 29 May 2020, from https://republika.co.id/ berita/pn9zc7328/ridwan-kamil-ungkap-alasannyahumoris-di-media-sosial 

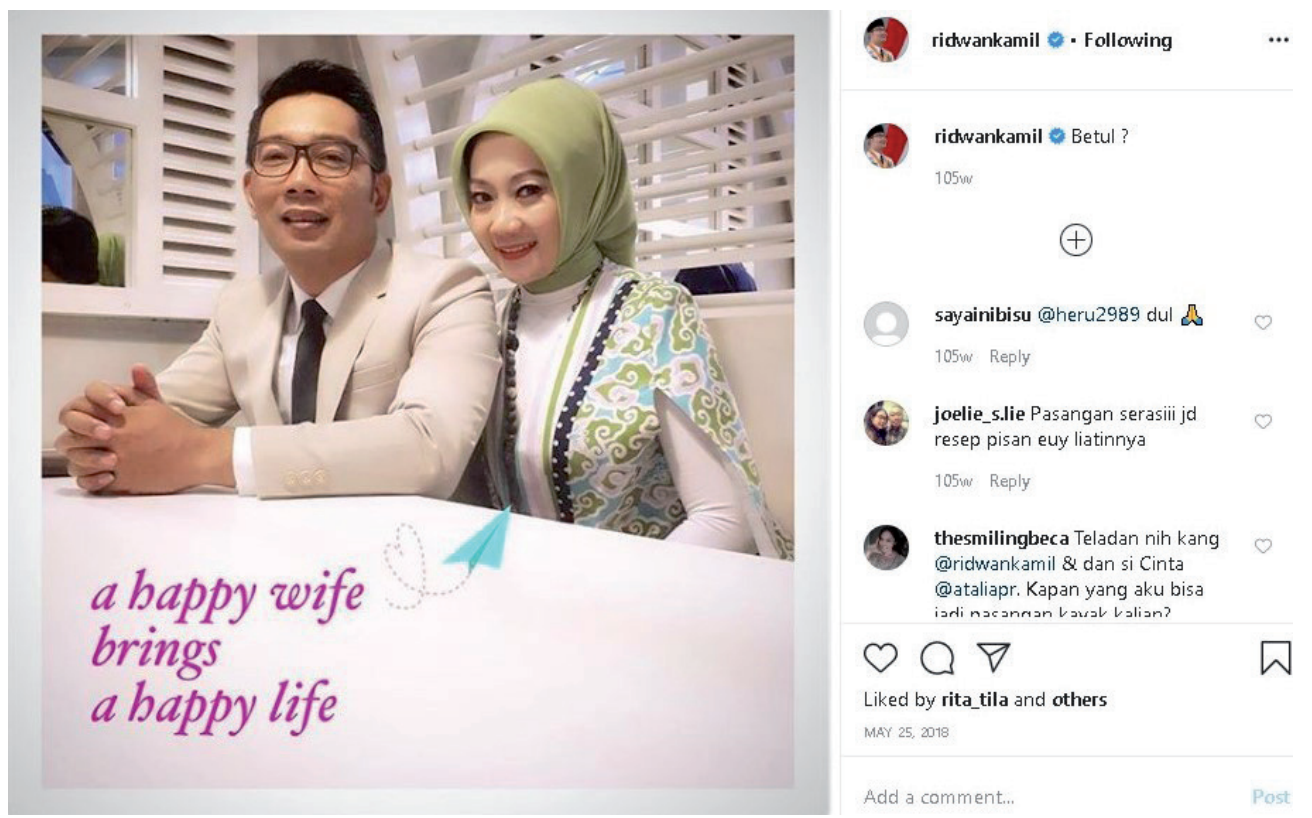

Picture 4. A happy wife brings happy life (25 May 2018)

the number of Instagram monthly active users in Indonesia has reached $61,610,000$ or 22.6 percent of Indonesia's total population. The largest age groups are between 18-24 that is 37.3 percent from total users. ${ }^{40}$ Social media construction of charisma by Ridwan Kamil therefore resonates to the largest portion of prospective voters.

The use of social media for Ridwan Kamil was also developing under the assumption that each social media platform has different characteristic of followers. For instance, Ridwan Kamil observed that many of his followers choose to convey their complaints about Bandung on Twitter. Meanwhile, Ridwan Kamil relates his Instagram followers more casually by sharing jokes and other lighter contents. This includes the representation of him and his wife as a romantic couple. The user of Facebook, on the other hand, is usually coming from older generations, hence Ridwan Kamil produced more balanced content. "As for Twitter, I think (I acted) like opinion maker, (because) many people are too serious there. Well, Instagram is (widely used by) millennial, so it is not as serious as on Twitter. So, I'm comfortable on Instagram, and occasionally

40 Pertiwi, W. K. (2019, December 23). Sebanyak Inikah Jumlah Pengguna Instagram di Indonesia? KOMPAS. Com. Retrieved 29 May 2020, from https://tekno. kompas.com/read/2019/12/23/14020057/sebanyakinikah-jumlah-pengguna-instagram-di-indonesia
I report serious things on Twitter, ${ }^{" 41}$ as stated by Ridwan Kamil. ${ }^{42}$

The strong base of young voters, were not enough to win election in West Java. Although Ridwan is well known especially in Bandung, the popularity of Deddy Mizwar as the incumbent West Java Vice Governor cannot be ignored. Moreover, as mentioned by Arfi Rafnialdi, ${ }^{43}$ West Java has many rural and remote areas that has not received Internet infrastructure. The lack of technological infrastructure thus limits the charismatic appeals that Ridwan Kamil built on social media. To solve this problem, his campaign team increased the number of volunteers who assign to greet and to introduce Ridwan Kamil as a candidate for governor.

41 Original version in Indonesian language: "Kalau Twitter, menurut saya seperti opinion maker lah, banyak yang terlalu serius di situ. Nah, kalau Instagram itu lebih milenial, jadi enggak seserius di Twitter. Jadi, saya nyaman di Instagram, dan sesekali di Twitter untuk melaporkan hal-hal yang serius,"

42 Sari, S. P. (2020, February 13). Aktif di Media Sosial, Ridwan Kamil Lebih Nyaman di Instagram. INews.ID. Retrieved 25 May 2020, from https://www.inews.id/ lifestyle/seleb/aktif-di-media-sosial-ridwan-kamil-lebihnyaman-di-instagram

43 Arfi Rafnialdi was Ridwan Kamil's advisor during Bandung mayoral and West Java Gubernatorial election. Currently, he serves as Ridwan's public policy expert and the daily chairman of the West Java Development Acceleration Team 


\begin{abstract}
"West Java, indeed, the level of digital communication is not as high as Bandung. After touring, we found an area that unfamiliar with Kang Emil (Ridwan). Usually that areas are not yet exposed to the internet. A remote area. Kang Emil is better (known by voters) in cities rather than in villages. We see that correlation.... The strategy is to increase the number of volunteers who willing to visit the houses and to greet the residents " ${ }^{\prime 44}$, (interview with Arfi, 26 April 2018, in Bandung)
\end{abstract}

In addition, to reach prospective voters in remote areas, Ridwan Kamil used AVATAR (Angkutan Virtual Aspirasi Tim Rindu) or virtual transportation for Ridwan-Uu aspirations which initiated by Buliitt Sisareza. By this campaign car, Ridwan-Uu appeared as an animated character that able to interact with voters (Syamsuddin et al., 2019).

To gain enough support needed to win the election, Ridwan Kamil also reinforced his association with religious trope. "I am the son of two simple parents, my grandfather is a kyai (Islamic preacher) who has eight pesantrens (Islamic boarding school). So, if anyone ask who is Ridwan Kamil, the answer is Ridwan Kamil is grandchild of kyai who has eight pesantrens, therefore many Islamic programs in Bandung like Maghrib Mengaji (Maghrib Koran recitation) and Subuh Berjamaah (Subuh prayer in the congregation) ${ }^{\prime 45}$ said Ridwan Kamil. ${ }^{46}$ At

44 Original version in Indonesian language: "Jawa barat memang tingkat serapan komunikasi digital belum setinggi Bandung. Setelah berkeliling, kami menemukan daerah yang belum kenal Kang Emil. Biasanya daerah yang belum terpapar internet. Daerah pelosok. Kang Emil lebih dikenal di kota bukan desa. Kami melihat ada korelasi itu. Karena Jawa Barat tantangannya bukan hanya urban, tapi juga rural, maka strateginya kami perbanyak relawan yang berjuang mendatangi rumah-rumah dan menyapa warga."

45 Original version in Indonesian language: "Saya anak dari dua orang yang sederhana, kakek saya kyai punya pesantren delapan. Jadi kalau ada yang nanya Ridwan Kamil siapa sebutin Ridwan Kamil itu cucu kyai punya pesantren delapan, makanya banyak program-program keislaman di Bandung seperti Maghrib mengaji dan Subuh berjamaah,"

46 Alamsyah, S. (2017, April 16). Di Sukabumi, Ridwan Kamil Mengaku Cucu Kyai Pemilik 8 Pesantren. Detiknews. Retrieved 27 April 2020, from https://news. detik.com/berita-jawa-barat/d-3475744/di-sukabumiridwan-kamil-mengaku-cucu-kyai-pemilik-8-pesantren the same time, Ridwan Kamil also still embrace the modern identity by proclaiming that his background came from two dimensions, an American-educated figure who is also rooted in pesantren. ${ }^{47}$

At the same time, the necessity to win the votes from rural voters with traditional Islamic background were also delegated to Ridwan Kamil, vice governor candidate, Uu Ruzhaul Ulum. $\mathrm{Uu}$ who was once the regent of Tasikmalaya (2011-2016) can hook traditional Islamic voters. Together, Ridwan and Uu can collaborate their concentration in urban and rural areas. "I have a lot of experience in taking care of innovation and urban areas, while Uu has experience in taking care of rural area," said Ridwan Kamil. ${ }^{48}$ The combination between social media campaign on urban areas, and direct meet up campaign on rural area delivered Ridwan Kamil a victory in West Java Governor election, albeit not as strong as his win in Bandung election, only securing 32.88 percent of votes. ${ }^{49}$

\section{LIMITATIONS OF DIGITAL CHARISMA}

As discussed in previous sections, from very early on, Ridwan Kamil has utilized social media to construct his charisma as the ideal representation of future political leader. Back in 2012, on the initial campaign for Ridwan Kamil in 2013 mayoral election, he only has $0.8 \%$ awareness from Bandung residents (Herdiansah, Gunawan, and Muhammad 2014, 2). The number is overturned a year later, when Ridwan Kamil and Oded Danial were elected as mayor and vice mayor in Bandung since 2013. Without neglecting other variables that contributed this win, Ridwan Kamil's social media utilization has demonstrated how the political charisma developed within the

47 BBC News Indonesia. (2018, January 9). Ridwan Kamil dan strategi media sosialnya: Kenapa selalu soal jomblo?. Retrieved 28 May 2020, from https://www.bbc. com/indonesia/trensosial-42319886

48 Post, T. J. (2018, January 8). Ridwan Kamil-Uu Ruzhanul Ulam backed by four parties for West Java run. The Jakarta Post. Retrieved 27 May 2020, from https://www. thejakartapost.com/news/2018/01/08/ridwan-kamil-uuruzhanul-ulam-backed-by-four-parties-for-west-java-run. html

49 Post, Ridwan Kamil-Uu. 
technology provided competitive edge for him as politician.

In this context, we should look into more details to comprehend how Ridwan Kamil's mediated charisma played the role to his success in politics. We argue that his political charisma is at least supported by four important tropes. These are the tropes that he consistently conveyed during both campaign in Bandung and West Java. First, is the representation of Ridwan Kamil as modern professional. As described before, the trope comes naturally for Ridwan Kamil since it could be identified easily with his background. He graduated from the most prestigious engineering school in Indonesia, took graduate degree and professional career in United States, and eventually known as successful architect in Indonesia. These trajectories presented Ridwan Kamil as candidate that would able to utilize his expertise to formulate professional solutions to break political impasse produced and maintained by established politicians. A persona that is projected as demonstrated when Ridwan Kamil challenged incumbent mayor of Bandung regarding the management of Babakan Siliwangi forest.

The second trope that supports the charisma of Ridwan Kamil was the representation that he is a religious figure. Ridwan Kamil utilizes this trope to demonstrate that despite his modern association, he is not neglecting traditional roots. To represent the association, Ridwan Kamil draw the story of his family origins that has strong ties with pesantren. Moreover, Ridwan Kamil also posted numerous religious activities to reinforce that religious values are still very important in his life. The particular trope was presented even more prominent during 2018 West Java Governor election, when Ridwan Kamil received numerous black campaign questioning his level of piety.

Another trope that is also essential for Ridwan Kamil's charismatic constitution is his representation as a family man. Ridwan Kamil's family related content is one of the most popular pictures among his Instagram followers. On many occasion, Ridwan Kamil posted his activities with family either on posed pictures or the one with seemingly taken by candid. Among those pictures, some would portray the whole member of the family, but even more often presents Ridwan Kamil with Atalia, his wife, as a romantic couple. This particular trope is interesting not just because it provides a glimpse of Ridwan Kamil's life for his followers. But more than that, these pictures often added with caption that used humorous tones and informal words meant to relate with younger demographics. By presenting himself as authoritative and relatable leader of family, it is implied that Ridwan Kamil is also an ideal leader in public office.

The fourth trope of Ridwan Kamil's charisma, is his association with youth and popular culture. Ridwan Kamil demonstrated this association with popular trend contents that also resonated to much of his online followers. One aspect in particular, is Ridwan Kamil's love towards football that he expressed not only to international football club such as Liverpool but also local one, like Persib. The latter club has stronger relevance to Ridwan Kamil's politic for many reasons. Persib is known to have long history and its supporters are known to be among the most militant football fans in Indonesia. The support toward Persib is also strongly rooted with the pride of being residents of Bandung (Hadi, 2017). Therefore, Ridwan Kamil's appearance with Persib served as reminder that he is the true representation of Bandung residents.

Aside from football, Ridwan Kamil also regularly draws other aspect of popular culture that demonstrates how well-verse he is with trends among youth. During the trend of Korean soap opera, Ridwan Kamil jokingly made remarks about his physical appearance that is comparable to Korean pop idol. When Dilan, teenlit novel based in Bandung, Ridwan Kamil posted picture with his wife imitating the protagonist in the novel. While this last trope does not appear as hard politics as represented by other tropes, it helps maintain his popularity among youth followers.

Each of these tropes is hardly new in Indonesian politics. Political leaders for instance have always been trying to portray themselves as both family figure and religious. While the other two charismas might have become more prominent after democratization in Indonesia, but still have 
some precedents in the past. Along that projection of traits, media also has been crucial in mediating these representations. Nevertheless, the ability of Ridwan Kamil to combine and communicate these tropes within relative short period of time is unlikely possible without the role of social media. On these platforms, Ridwan Kamil and his team carefully produced the charisma to be presented to prospective voters.

The other aspect that is prominent on the entanglement between charisma and social media is the further personalization of politics. The aspect of personal figure, whether family, hobbies, football references arguably has become much more important aspect of politics than the proposed policies. As demonstrated from Ridwan Kamil's social media, the most popular contents are the ones that portray the personal aspect of his life. The personalization of politics was already raised as the characteristic of Ridwan Kamil's utilization of Twitter (Iqbal, 2016), a platform that was mainly designed for short text. However, the exploit of personal life is even more apparent on Instagram, social media that was designed mainly to display visual contents. While Indonesian politicians in the past is no stranger on the use of personal life in politics, the affordances of social media have blurred the boundaries between private and public in politics even further.

This is a situation that could also be found in global politics as well. Similar to Ridwan Kamil, Justin Trudeau, the Prime Minister of Canada, is known to be savvy politicians in using his personal life on social media to gain and maintain his influence (Lalancette \& Raynauld, 2017). Study on Instagram accounts used by Swedish politicians also demonstrated how personal contents have much more engagements with audiences in comparison to formal political contents (Ekman $\&$ Widholm, 2019). Therefore, while the use of personal life in politics is not a new phenomenon, the affordances of social media in particular visual based platform like Instagram, deepen the entrenchment of private into public representation even further.

Despite its crucial role, it is important to understand that the formation of charisma on social media is not without its limitations. The limitation could only be comprehended by looking into previous proposition that the notion of charisma is bounded by the local contexts attached to the leaders. As previously discussed, despite attributing the quality to individual leader, Weber's notion of charisma is dependent to the followers. Should the followers perceived that the leader has lost the charisma, the leader no longer has the capability to influence them. In this regard, as pointed out by Anderson (1990a), the cultural, political, and geographical boundaries play a big role in shaping the perception regarding charismatic leader.

Let us back into the figure represented by Ridwan Kamil in social media. The aforementioned tropes have enabled Ridwan Kamil to present himself as a new breed of politicians. To certain extent, the perception is justified since his modern appeal seem to look contrasts with the image of common bureaucrats. However, Ridwan Kamil's charismatic figure is only able to be accepted because the tropes he represents is not alien at all to Bandung residents, or even Indonesian citizen in general. Bandung for a long time is known for its cosmopolitan characteristics, it is vibrant with creative industry, and associated with ITB, an engineering school that contributes in the proliferation of creative culture (Aritenang, 2013). Against this background, Ridwan Kamil's education and established professional career in creative industry is very much fits the idealization of successful Bandung residents.

In larger context, the persona of Ridwan Kamil as modern leader that pursue development through technological advancement is also familiar trope in Indonesian politics. Amidst the height of New Order, Suharto envisaged that Indonesia will be developed into technological state (Amir, 2013). The key figure to fulfill the vision was B. J. Habibie, which was later become the third president of Indonesia. Similar to Ridwan Kamil, B. J. Habibie was graduated from engineering school of Western education. Also comparable to Ridwan Kamil, Habibie believes the importance of technology and science of Indonesian development. At the same time, Habibie was also known as the proponent of ICMI (Ikatan Cendekiawan 
Muslim Indonesia) that pursue the integration between Islamic identity and scientific based development (Hefner, 2000). BJ Habibie in this regard, has set a precedent of Indonesian leader whose charisma is attached to the imagination of technological excellence. It is similar to the role performed by Ridwan Kamil both in Bandung and West Java through his social media account. As a technology, social media in this regard is more than just communication medium. It also serves to reinforce even further the association of Ridwan Kamil to modern scientific advancement.

The role of political context is also apparent on other tropes, such as religious and family association. Scholars on Indonesian politics are not strange to the idea that family representation has been prominent for a long time. The state is envisaged by many Indonesian to be the larger representation of family. This idea could be traced to organicist thinking back in the early formation of Indonesia as a nation (Bourchier, 2015). Later, New Order under the leadership of Suharto institutionalized this thinking even further thus made it deeply entrenched in Indonesian politics, including daily interactions within family. (Shiraishi, 1997). As a consequence of this thinking, the harmony of family is seen as one of important tools to measure the quality of leadership by politicians. Therefore, it is almost imperative for any public officials campaigning for political office, trying to represent themselves as an authoritative leader of harmonious family. Within this context, family contents Ridwan Kamil posted on Instagram is not merely a presentation of personal picture, rather an active performance of leadership capacity.

The same limitation also applied to Ridwan Kamil's persona of being religious figure. In the context of Islamized public sphere in Indonesia (Bruinessen, 2013), there will not be any public politicians that dare to oppose Islamic normativities. This is even more relevant after the 212 religious rally, that demonstrated how religious leaders could not do much against religiously motivated political demands (Burhani, 2016). In particular to West Java, religious practices even has shaped the public decorum that left no other options for aspiring politicians other than try to be perceived as religious (Millie, 2018). Against the backdrop, it is understandable if Ridwan Kamil felt the necessity to present themselves as a religious leader. The need to identify with Islamic symbols is even more crucial for Ridwan Kamil in 2018 West Java Governor Election, since he was attacked with black campaign questioning his religious commitment.

The same limitations also explain the previous criticism addressed to Ridwan Kamil's sexist remarks both regarding the role of women and LGBT community. Regardless of the actual intentions of the posts, Ridwan Kamil's position on both issues arguably represents the dominant discourse in society. The institutionalization of women's domestic role for instance, has long been recorded in Indonesian politics (Robinson, 2018). This is also the case with LGBT community group that on daily basis still experienced discrimination (Wijaya, 2019). The dominant culture is apparent when despite some online backlash, both remarks did not have any actual impact on the acceptability of Ridwan Kamil among Bandung residents.

The limitation of social media in pushing beyond dominant narrative paralleled the observation made by Lim (2013) regarding online social movement. She posited that it is hard for online movement to be translated into offline mobilization should it is framed against the dominant narrative in Indonesia. The case of Ridwan Kamil presented on this article, demonstrated that the same limitation is also relevant for charismatic leaders on social media. As much as Ridwan Kamil try to represent himself as the new generation of politicians, it is unlikely that he would propose political causes that contradict general norms and values. Even more so should the causes perceived by the leaders would be detrimental for their charismatic persona. On this aspect, Ridwan Kamil does not seem to be that different from other politicians, despite his effort to present himself as an outsider from political status quo. 


\section{CONCLUSION}

The article exploration on ties between social media and contemporary political charisma in Indonesia, is traced from the debates on the role of charisma and power that has strong relevance in the study of Indonesian politics (e.g. (Anderson, 1990b; Hughes-Freeland, 2007). Based on these debates, the empirical cases of power and Indonesia offered a new insight to comprehend how charisma shapes the influence of leader to their followers. Cases in Indonesia has demonstrated that charismatic leader should not be perceived as a temporary phenomenon (as suggested in the original proposition of Weber), rather could also be seen as an essential feature of politics even within the democratic political system.

Among the most important aspect for the construction of charisma is media, including social media that these days have become crucial element of political campaign for any aspiring politicians. The article then looks into Ridwan Kamil's utilization of social media, to understand how politicians developed political charisma needed to climb political ladder. The article suggests that Ridwan Kamil and his team are able to optimize social media affordances, by representing himself into multiple tropes resonates to local contexts. The main tropes were modern professional, religious figure, family man, youth and popular culture. On social media, Ridwan Kamil could developed specific political charisma based on those tropes without being bothered with gatekeepers of information like the one usually found on traditional media. This utilization of social media thus facilitated Ridwan Kamil to present himself as fresh figure into Indonesian politics, yet is still acceptable for common political norms.

At the same time, we have also addressed some limitations to political charisma developed on social media. Since the charisma on social media platform tends to conform with social and cultural norms, the politician also could not address political issues that is perceived to be against dominant values. In the case of Ridwan Kamil, some contents on his social media suggest that his political position shared bias toward woman and LGBT community that are existing within society. In this regard, despite the incorporation of social media as a new technology, it does not automatically produce out of the box political position.

What does it mean then for the future of Indonesian politics? As of today, the use of social media among aspiring politicians is much more prominent in comparison to even five years ago. Their presence on social media, has been functional for some of politicians to provide much more exposure to their figure and political programs. Granted, the exposure often still attached to predisposed bias in society. Head of Luwu Utara, small district in Sulawesi for instance, gained attention nationally from her picture on Instagram, where she (portrayed by media as a beautiful woman) rides motorcycle riding trail motorcycle to deliver essential goods on remote areas..$^{50}$ Many others probably do not gain any attention outside his political region. Nonetheless, it is inevitable that the utilization this technology would have much more impact to Indonesian politics.

One effect in particular could be seen on the personalization of politics. While the reliance on personal figure instead of political party on politics has long been observed (Aspinall \& Berenschot, 2019; Budiatri et al., 2018; Ufen, 2006), the affordances of social media will reinforce the tendency even stronger. As discussed, the characteristic of social media campaign tends to favors personalization of politics, in which the presentation of personal contents gained more reward in term of followers and engagement rather than formal contents. This is not only demonstrated on the case of Ridwan Kamil, but is also relevant to other politicians that could strategically exploit these features. In consequence, there could be more aspiring politicians to employ similar strategy and further eclipse the role of political institutions such as party.

The proposition we make in this article should not be understood in neglecting other aspects of politics that contribute to both Kamil's win in election. On election for instance, while

50 https://news.detik.com/berita/d-5053514/tiga-aksiatraktif-bupati-luwu-utara-pengabdian-atau-pencitraan (accessed 17 June 2020) 
interdependent connections between grassroots movement and social media is crucial in his campaign, Ridwan Kamil's political career is also shaped by political parties (Herdiansah et al., 2014). On 2018 West Java Gubernatorial campaign, it was also acknowledged that the influence of Ridwan Kamil is not as much in areas without Internet access. Social media in this regard, is influential in helping politicians to build political charisma but at the same time is limited to constraints attached to the old structure of Indonesian politics.

\section{REFERENCE}

Aberbach, D. (1996). Charisma in Politics, Religion and the Media. Palgrave Macmillan.

Adair-Toteff, C. (2005). Max Weber's Charisma. Journal of Classical Sociology, 5(2), 189-204. https://doi.org/10.1177/1468795X05053491

Amir, S. (2013). The Technological State in Indonesia: The co-constitution of high technology and authoritarian politics. Routledge.

Anderson, B. (1990a). Further Adventures of Charisma. In Language and Power: Exploring Political Cultures in Indonesia (pp. 78-93). Cornell University Press.

Anderson, B. (1990b). The Idea of Power in Javanese Culture. In Language and Power: Exploring Political Cultures in Indonesia (pp. 17-77). Cornell University Press.

APJII. (2019). Penetrasi \& Profil Perilaku Pengguna Internet Indonesia Survei (2018).

Aritenang, A. (2013). Antecedent Analysis of Indonesia 's Creative City: The Case of Bandung. In P. Mandal (Ed.), Proceeding of the International Conference on Managing the Asian Century (pp. 139-144). Springer Science + Business Media Singapore. https://doi.org/10.1007/978981-4560-61-0

Aspinall, E. (2015). Oligarchic Populism : Prabowo Subianto' s Challenge to Indonesian Democracy. Indonesia, 99, 1-28. https://doi. org/10.1353/ind.2015.0002

Aspinall, E., \& Berenschot, W. (2019). Democracy for Sale: Pemilihan Umum, Klientelisme, dan Negara di Indonesia. Yayasan Obor Indonesia.

Borah, P. (2016). Political Facebook Use: Campaign Strategies Used in 2008 and 2012 Presidential Elections. Journal of Information Technology \& Politics, 13(4), 326-338. https://doi.org/10. 1080/19331681.2016.1163519
Bourchier, D. (2015). Illiberal Democracy in Indonesia: The ideology of the family state. Routledge.

Bruinessen, M. Van (Ed.). (2013). Contemporary Developments in Indonesian Islam: Explaining the "Conservative Turn." ISEAS Publishing.

Budiatri, A. P., Haris, S., Romli, L., Nuryanti, S., Nurhasim, M., Amalia, L. S., Darmawan, D., \& Hanafi, R. I. (2018). Personalisasi Partai Politik di Indonesia Era Reformasi. Jurnal Penelitian Politik, 15(2), 289-306.

Burhani, A. N. (2016). Aksi Bela Islam : Konservatisme dan Fragmentasi Otoritas Keagamaan. Maarif, 11(2), 15-29.

Derman, J. (2012). Max Weber in Politics and Social Thought: From Charisma to Canonization. Cambridge Univ Press.

Ekman, M., \& Widholm, A. (2019). Political communication in an age of visual connectivity : Exploring Instagram practices among Swedish politicians. Northern Lights, June 2017, 15-32. https://doi.org/10.1386/nl.15.15

Fuady, A. H. (2018). Teknologi Digital dan Ketimpangan Ekonomi di Indonesia. Masyarakat Indonesia, 44(1), 75-88.

Hadi, A. (2017). "Bobotoh Persib" dan Konstruksi Identitas di Era Digital. Jurnal Masyarakat \& Budaya, 19(1), 131-152.

Hadi, A. (2018). Bridging Indonesia's Digital Divide: Rural-Urban Linkages? Jurnal Ilmu Sosial Dan Ilmu Politik, 22(1), 17-33. https://doi. org/10.22146/jsp.31835

Hefner, R. W. (2000). Civil Islam: Muslims and Democratization in Indonesia. Princeton University Press.

Herdiansah, A. G., Gunawan, W., \& Muhammad, R. A. T. (2014). Gerakan Komunitas Kota dan Politik Pemilu dalam Pemenangan Ridwan Kamil- Oded Danial pada Pemilihan Walikota Bandung 2013. Konferensi Nasional Sosiologi III, 20-22 Mei, 1-14.

Hootsuite. (2019). DIGITAL 2019: INDONESIA.

Hughes-Freeland, F. (2007). Charisma and celebrity in Indonesian politics. Anthropological Theory, 7(2), 177-200.

Hunter, W., \& Power, T. J. (2019). Bolsonaro and Brazil 's Illiberal Backlash. Journal of Democracy, 30(1), 68-82.

Iqbal, M. (2016). Ridwan Kamil for Mayor: A study of political figure on Twitter. Stockholm University.

Kenny, P. D. (2019). Populism in Southeast Asia (E. Aspinall \& M. L. Weiss (Eds.)). Cambridge Univ Press. 
Kitley, P. (1994). Fine Tuning Control: Commercial Television in Indonesia. Australian Journal of Media and Culture, 8, 103-123.

Lalancette, M., \& Raynauld, V. (2017). The Power of Political Image : Justin Trudeau, Instagram, and Celebriti Politics. American Behavioral Scientist, 00(1-37). https://doi. org/10.1177/0002764217744838

Lim, M. (2013). Many Clicks but Little Sticks : Social Media Activism in Indonesia. Journal of Contemporary Asia, 43(4), 636-657. https:// doi.org/10.1080/00472336.2013.769386

Lim, M. (2017). Freedom to hate: social media, algorithmic enclaves, and the rise of tribal nationalism in Indonesia. Critical Asian Studies, 49(3), 1-17. https://doi.org/10.1080/1467 2715.2017.1341188

Marshall, D. (1997). Celebrity and Power. University of Minessota Press.

Mietzner, M. (2009). Indonesia's 2009 Elections : Populism, Dynasties and the Consolidation of the Party System (Issue May).

Mietzner, M. (2014). How Jokowi Won and Democracy Survived. Journal of Demo, 25(4), 111-125. https://doi.org/10.1353/jod.2014.0073

Miichi, K. (2014). The Role of Religion and Ethnicity in Jakarta's 2012 Gubernatorial Election. Current Southeast Asian Affairs, 33(1), 55-83.

Millie, J. (2018). An Anthropological Approach to the Islamic Turn in Indonesia 's Regional Politics. TRaNS: Trans - Regional and - National Studies of Southeast Asia, 6(2), 207-226. https:// doi.org/10.1017/trn.2018.6

Mudde, C., \& Kaltwasse, R. (2014). Populism and Political Leadership. In R. A. W. Rhodes \& P. 'T Hart (Eds.), The Oxford Handbook of Political Leadership (pp. 296-305).
Norris, P., \& Inglehart, R. (2019). Cultural Backlash: Trump, Brexit, and Authoritarian Populism. Cambridge University Press.

Robinson, K. (2018). Gender Culture and Politics in Post-New Order in Indonesia. In R. W. Hefner (Ed.), Routledge Handbook of Contemporary Indonesia (pp. 309-321).

Rojek, C. (2001). Celebrity. Reaktion Books.

Shiraishi, S. S. (1997). Young Heroes: The Indonesian Family in Politics. Cornell Southeast Asia Program.

Syamsuddin, D., Wijaya, V., \& Bernando, A. (2019). The phenomenon of blusukan strategy with 3D AVATAR concept in political campaign of West Java governor ( A case study : Mr Ridwan Kamil and Mr Uu Ruzhanuk Ulum as candidate election ). International Conference on Advance and Scientific Innovation (ICASI), 1-6. https:// doi.org/10.1088/1742-6596/1175/1/012241

Ufen, A. (2006). Political Parties in Post-Suharto Indonesia : Between politik aliran and 'Philippinisation ' (Issue 37).

Weber, M. (1946). The Sociology of Charismatic Authority. In From Max Weber: Essays in Sociology (pp. 245-253). Oxford University Press.

Weber, M. (1947). MAX WEBER : The Theory of Social and Economic Organization. The Free Press.

Widyawati, N. (2014). Etnisitas dan Agama Sebagai Isu Politik: Kampanye Pemilu JK-Wiranto pada Pemilu 2009. Yayasan Obor Indonesia.

Wijaya, H. Y. (2019). Localising queer identities: queer activisms and national belonging in Indonesia. In G. Fealy \& R. Ricci (Eds.), Contentious Belonging : The Place of Minorities in Indonesia (pp. 133-154). ISEAS Publishing. 